\title{
Investigation of Gene Expression of MMP-2 and TIMP-2 mRNA in Rat Lung in Inhaled Nickel Oxide and Titanium Dioxide Nanoparticles
}

\author{
Yasuo MORIMOTO' ${ }^{*}$, Takako OYABU ${ }^{1}$, Akira OGAMI', Toshihiko MYOJO¹, \\ Etsushi KURODA ${ }^{2}$, Masami HIROHASHI ${ }^{1}$, Manabu SHIMADA ${ }^{3}$, \\ Wuled LENGGORO ${ }^{3}$, Kikuo OKUYAMA ${ }^{3}$ and Isamu TANAKA ${ }^{1}$
}

\author{
${ }^{1}$ Institute of Industrial Ecological Sciences, University of Occupational and Environmental Health, Japan, \\ Yahatanishiku Iseigaoka 1-1, Kitakyushu, Fukuoka 807-8555, Japan \\ ${ }^{2}$ School of Medicine, University of Occupational and Environmental Health, Japan, Fukuoka, Japan \\ ${ }^{3}$ Graduate School of Engineering, Hiroshima University, Hiroshima, Japan
}

Received June 17, 2010 and accepted October 7, 2010

Published online in J-STAGE March 1, 2011

\begin{abstract}
In order to investigate whether or not dispersed nanoparticles have an effect of inflammation and fibrosis on animals, we developed a nanoparticle generation system and examined the gene expression of matrix metalloproteinase (MMP) and tissue inhibitor matrix proteinase (TIMP) in rat lung containing inhaled nickel oxide $(\mathrm{NiO})$ or titanium dioxide $\left(\mathrm{TiO}_{2}\right)$ nanoparticles. In both experiments, Wistar male rats were exposed to $\mathrm{NiO}$ or $\mathrm{TiO}_{2}$ nanoparticles for $4 \mathrm{wk}(6 \mathrm{~h} /$ day $)$. The geometric mean diameters of $\mathrm{NiO}$ and $\mathrm{TiO}_{2}$ in the chamber were $139 \pm 12 \mathrm{~nm}$ and $51 \pm 9 \mathrm{~nm}$, respectively. The average concentration of the particle number of $\mathrm{NiO}$ and $\mathrm{TiO}_{2}$ was $1.0 \mathrm{E}+05 / \mathrm{cm}^{3}$ and $2.8 \mathrm{E}+05 / \mathrm{cm}^{3}$, respectively. At $4 \mathrm{~d}, 1$ and 3 months after the end of the inhalation, the rats exposed to these particles were sacrificed and the gene expressions of MMP-2, TIMP-2 and type I collagen were measured using RT-PCR. Pathological finding revealed that there was minimum inflammation with nickel oxide only at $4 \mathrm{~d}$ and no change with titanium oxide. However, there were no changes of the gene expression of MMP-2, TIMP-2, and type I collagen in either the $\mathrm{NiO}$ or $\mathrm{TiO}_{2}$ exposure groups. In this study, inhalation of nickel oxide and titanium dioxide nanoparticles did not induce the gene expression of MMP-2 and TIMP-2 mRNA in rat lungs.
\end{abstract}

Key words: Nanoparticle, Inhalation study, Nickel oxide, Titanium dioxide, Matrix

\section{Introduction}

Manufactured nanomaterial is an intentionally produced structure of which at least one of 3 dimensions is about $1 \mathrm{~nm}-100 \mathrm{~nm}^{1)}$. Animal studies have reported that particle matter 2.5 (PM2.5), including ultrafine particle, and diesel particles have an influence on organs such as brain and testis, which are not open to direct exposure $^{2-6)}$, and a low dose of particles induces pulmonary inflammation ${ }^{6,7)}$; these results lead to concern that

*To whom correspondence should be addressed.

E-mail: yasuom@med.uoeh-u.ac.jp manufactured nanomaterial, may have similar biological effects. The lung is a target organ of nanoparticle exposure, and reports have described workers showing severe pulmonary inflammation and fibrosis due to inhalation exposure to nanoparticles ${ }^{8}$.

Extracellular matrix is closely associated with this inflammation and subsequent fibrosis ${ }^{9)}$. Extracellular matrix (ECM) deposition presumably depends on a balance between synthesis and degradation of collagen ${ }^{9}$. Degradation of collagen is regulated by matrix metalloproteinase and the tissue inhibitors of metalloproteinases (TIMPs); matrix metalloproteinases (MMPs) are a family of zinc and calcium-dependent endopeptidases 


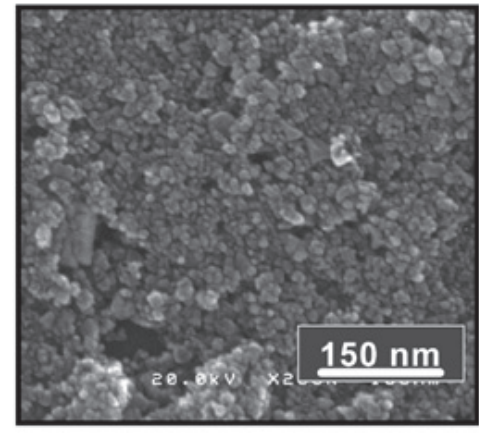

Raw materials

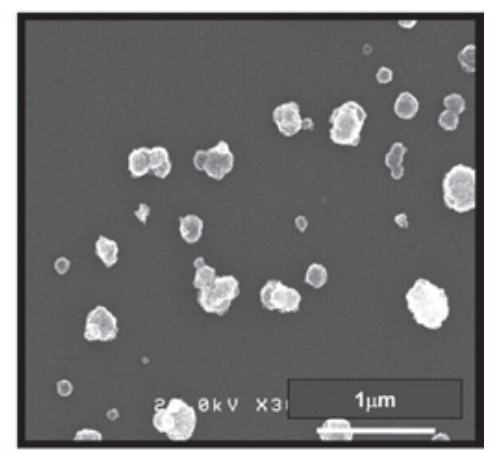

Particles in the chamber

Fig. 1. Scanning electron photomicrograph of $\mathrm{NiO}$ nanoparticles in inhalation chamber.

that play a key role in ECM remodeling in the lung ${ }^{9)}$. MMPs have the combined ability to degrade the various components of connective tissue matrices, specifically directed to ECM components. However, the activities of MMPs are controlled at several levels including their interactions with specific inhibitors, the tissue inhibitors of metalloproteinases (TIMPs). An imbalance of MMPs and TIMPs has been reported to result in metalloproteinase activation or inactivation, and relative levels of MMPs rather than of TIMPs may contribute to the degradation or deposition of collagen in the interstitial space. If the imbalance of these proteins leads to infiltration of inflammatory cells, persistent inflammation, and excessive deposition of collagen, fibrosis may progress $^{9)}$.

We had already developed two inhalation exposure systems to disperse nanoparticles to exposure in a previous inhalation exposure study, and reported that nanoparticles were deposited in the lung. The present study examines the expression of MMP and TIMP, which are genes related to inflammation and fibrosis, in an inhalation exposure study of nickel oxide $(\mathrm{NiO})$ and titanium dioxide $\left(\mathrm{TiO}_{2}\right)$ nanoparticles.

\section{Subjects and Methods}

\section{Materials}

The NiO sample $(20 \mathrm{~nm}$ nominal primary diameter, 99.8\% purity) was purchased from Nanostructured \& Amorphous Materials Inc. The Brunauer-Emmett-Teller (BET) specific surface area of the measured sample was $104.6 \mathrm{~m}^{2} / \mathrm{g}$ and weighted average surface primary diameter (Sauter diameter) was $8.41 \mathrm{~nm}$.

The $\mathrm{TiO}_{2}$ particles (rutile) were purchased from Ishihara Industry. The primary diameter of the $\mathrm{TiO}_{2}$ was $35 \mathrm{~nm}$.

\section{Inhalation study of $\mathrm{NiO}$}

The generation and inhalation system of $\mathrm{NiO}$ nanoparticles was described in our previous paper ${ }^{10)}$. The generation system was mainly composed of an ultrasonic nebulizer and diffusion dryers, connected to an exposure chamber $\left(0.52 \mathrm{~m}^{3}\right)$. The dynamic air flow was kept to be 12 to 15 air changes per hour in the chamber. Droplets containing $\mathrm{NiO}$ nanoparticles were dispersed in air by spray-drying an aqueous suspension using an ultrasonic nebulizer; next, the aqueous component in the droplets was removed using diffusion dryers to obtain $\mathrm{NiO}$ aerosol nanoparticles.

The electron microphotographs of the original $\mathrm{NiO}$ particles (raw material) and those in the exposure chamber are shown in Fig. 1. The size and number concentrations of the particles in the chamber were analyzed in-line using a particle spectrometer consisting of a differential mobility analyzer and a condensation particle counter (Model 1000XP WPS, MSP Corp., Shoreview, $\mathrm{MN})$ throughout the exposure period, and the average of diameter and number concentration of the particles in the chamber was measured at all exposure day.

\section{Inhalation study of $\mathrm{TiO}_{2}$}

The generation and inhalation system employed for the $\mathrm{TiO}_{2}$ sample is essentially the same as the one used for different kinds of nanoparticles ${ }^{11)}$. It consisted of a pressurized nebulizer and a mist dryer, connected to an exposure chamber $\left(0.52 \mathrm{~m}^{3}\right)$. The dynamic air flow in the chamber was same to that in inhalation of $\mathrm{NiO}$. In this study, a $\mathrm{TiO}_{2}$ nanoparticle suspension was put into the air using the pressurized nebulizer, and its aqueous component was removed by a mist dryer. The electron micrographs of the $\mathrm{TiO}_{2}$ particles before and after they were dispersed in air are shown in Fig. 2. The size and number concentrations of the particles in the chamber were analyzed in-line using a particle spectrometer consisting of a differential mobility analyzer and a con- 


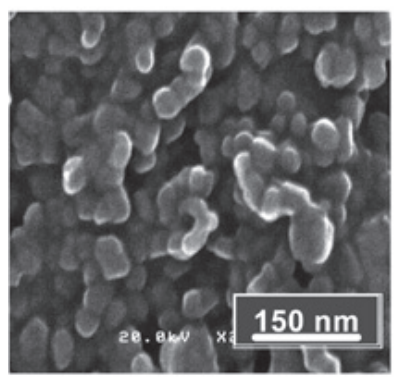

Raw materials
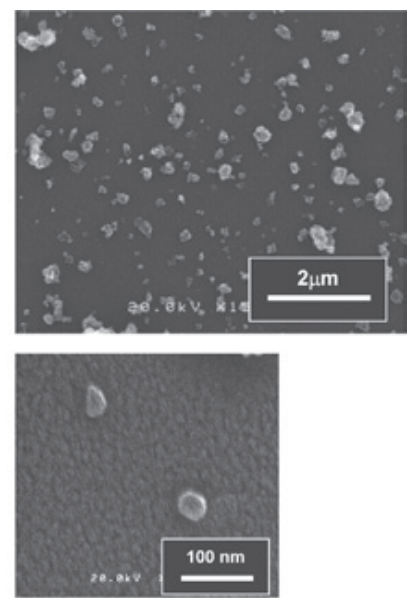

Particle in chamber

Fig. 2. Scanning electron photomicrograph of $\mathrm{TiO}_{2}$ nanoparticles in inhalation chamber.

densation particle counter (Model 1000XP WPS, MSP Corp., Shoreview, MN) throughout the exposure period, and the average of diameter and number concentration of the particles in the chamber was measured at all exposure day.

\section{Animals}

Ninety Wistar male rats (9-wk old) were divided into three groups: the unexposed group and 2 exposed groups which were exposed by inhalation to $\mathrm{NiO}$ or $\mathrm{TiO}_{2}$ for 4 wk $(6 \mathrm{~h} /$ day, $5 \mathrm{~d} /$ week $)$. Each group had 30 rats, and was kept in an inhalation chamber and control rats (unexposed group) were exposed to fresh air only. Ten rats from each group were randomly sacrificed at $4 \mathrm{~d}, 1$ month and 3 months after the 4 wk exposure.

Each group was divided into 2 subgroups of 5 animals. The first subgroup (5 rats) provided bronchoalveolar lavage, which was collected using physiological saline that was poured through a cannula inserted in the respiratory tract into the right lung, while the left lung was clamped. Three $-10 \mathrm{ml}$ of physiological saline was infused per time and lavage fluid was collected up to $50 \mathrm{ml}$ in total. The left lung was inflated and fixed by intratracheal instillation of $4 \%$ paraformaldehyde at $25 \mathrm{~cm} \mathrm{H}_{2} \mathrm{O}$ pressure. The lungs of the second subgroup (5 rats) were homogenized to extract mRNA.

The rats were handled according to the guidelines described in the Japanese Guide for the Care and Use of Laboratory Animals as approved by the Animal Care and Use Committee, University of Occupational and Environmental Health, Japan.
Preparation of RNA, cDNA Synthesis, and polymerase chain reaction

RNA was extracted from the lung using $\mathrm{RNeasy}(\mathrm{R})$ Mini Kit (50) (QIAGEN Hilden, Germany). Singlestrand cDNA was synthesized using High Capacity cDNA Reverse Transcription Kit (Applied Biosystems, CA.). Single-strand cDNA was synthesized with moloney murine leukemia virus-derived reverse transcriptase (Perkin Elmer, Norwalk, Connecticut, USA) using $500 \mathrm{ng}$ of total RNA. An equal amount of cDNA from each sample was amplified by specific primers for each gene (Table 1). Amplification was performed with a thermocycler (Astech, Japan) under the following conditions: denaturation at $94^{\circ} \mathrm{C}$ for $45 \mathrm{~s}$, annealing at $60^{\circ} \mathrm{C}$ for $45 \mathrm{~s}$, and extension at $72^{\circ} \mathrm{C}$ for $2 \mathrm{~min}$ for the target and $\beta$-actin genes.

The fragments amplified by polymerase chain reaction (PCR) were detected by electrophoresis on $2 \%$ agarose gel. The PCR products were resolved using gel electrophoresis and visualized by ethidium bromide staining. The gel was photographed with Polaroid Type 665 positive/negative film (Polaroid Corporation, Cambridge, Mass., USA) under ultraviolet light at identical exposure and development times. The bands from the positive film were scanned, and the density of MMP-2 and TIMP-2 product was measured using National Institute of Health (NIH) Image 1.55 software (written by Wane Rasband at NIH, Bethesda, MD).

\section{Tissue preparation for HE stain}

After removal of the lungs, the left lung was inflated and fixed by intratracheal instillation of $4 \%$ paraformaldehyde at $25 \mathrm{~cm} \mathrm{H}_{2} \mathrm{O}$ pressure. The lungs and trachea were resected from the surrounding tissue, and allowed 
Table 1. Oligonucleotide of primers of four target genes

\begin{tabular}{|c|c|c|c|}
\hline \multirow{2}{*}{ mRNA species } & \multirow{2}{*}{ mRNA } & \multicolumn{2}{|c|}{ PCR product } \\
\hline & & Cycle & bp \\
\hline MMP-2 & $\begin{array}{l}\text { (sense) 5'- GAGATCTGCAAACAGGACAT } \\
\text { (antisense) 5'- GGTTCTCCAGCTTCAGGTAA }\end{array}$ & 39 & 528 \\
\hline TIMP-2 & $\begin{array}{l}\text { (sense) 5' - AATGACATCTATGGCAACCCC } \\
\text { (antisense) 5'-AAGAACCATCACTTCTCTTG }\end{array}$ & 34 & 426 \\
\hline Type I collagen & $\begin{array}{l}\text { (sense) 5'-CAAGAATGGCGACCGTGGTGA } \\
\text { (antisense) 5'- GGTGTGACTCGTGCAGCCATC }\end{array}$ & 34 & 1074 \\
\hline$\beta$-actin & $\begin{array}{l}\text { (sense) 5'-ATCATGTTTGAGACCTTCAACACC } \\
\text { (antisense) 5'- TAGCTCTTCTCCAGGGAGG }\end{array}$ & $26-28$ & 357 \\
\hline
\end{tabular}

Table 2. Weight and organ weights of rats in inhalation studies of nanoparticles

\begin{tabular}{lccccc}
\hline & Weight $(\mathrm{g})$ & Lung $(\mathrm{g})$ & Liver $(\mathrm{g})$ & Kidney $(\mathrm{g})$ & Spleen $(\mathrm{g})$ \\
\hline $4 \mathrm{~d}$ & & & & & \\
$\quad$ Unexposed & $400 \pm 20$ & $1.74 \pm 0.17$ & $13.8 \pm 1.0$ & $2.34 \pm 0.19$ & $0.84 \pm 0.13$ \\
$\quad \mathrm{NiO}$-exposure & $413 \pm 34$ & $2.02 \pm 0.23$ & $14.4 \pm 1.8$ & $2.42 \pm 0.21$ & $0.90 \pm 0.09$ \\
$\quad \mathrm{TiO}_{2}$-exposure & $389 \pm 27$ & $1.74 \pm 0.07$ & $13.5 \pm 1.4$ & $2.39 \pm 0.24$ & $0.84 \pm 0.17$ \\
1 month & & & & & \\
Unexposed & $502 \pm 27$ & $1.64 \pm 0.14$ & $16.6 \pm 1.8$ & $2.74 \pm 0.27$ & $0.84 \pm 0.07$ \\
NiO-exposure & $495 \pm 39$ & $1.58 \pm 0.12$ & $15.8 \pm 1.5$ & $2.77 \pm 0.29$ & $0.85 \pm 0.12$ \\
TiO -exposure & $524 \pm 47$ & $1.68 \pm 0.32$ & $17.0 \pm 1.9$ & $2.84 \pm 0.20$ & $0.89 \pm 0.14$ \\
3 months & & & & & \\
Unexposed & $568 \pm 55$ & $1.63 \pm 0.18$ & $18.2 \pm 2.6$ & $3.03 \pm 0.28$ & $0.80 \pm 0.11$ \\
$\quad \mathrm{NiO}^{-}$-exposure & $552 \pm 37$ & $1.75 \pm 0.11$ & $16.9 \pm 1.2$ & $2.90 \pm 0.19$ & $0.88 \pm 0.08$ \\
$\mathrm{TiO}_{2}$-exposure & $576 \pm 50$ & $1.67 \pm 0.06$ & $18.2 \pm 2.1$ & $2.90 \pm 0.22$ & $0.89 \pm 0.10$ \\
\hline
\end{tabular}

Rat and organ weight $(\mathrm{g})$ by inhaled nanoparticles. Each column and bar represents the mean \pm SD of ten rats.

to stand at $4^{\circ} \mathrm{C}$ for $24 \mathrm{~h}$. The tissue was washed for $10 \mathrm{~min}$ in phosphate-buffered saline, dehydrated by immersion in a graded series of ethanol washes for $1 \mathrm{~h}$ per wash, then maintained in $100 \%$ ethanol at $4^{\circ} \mathrm{C}$. The lung tissue was embedded in paraffin, and $5 \mu \mathrm{m}$-thick sections were cut from the lobe. The samples were then sectioned and stained with hematoxylin and eosin.

\section{Statistical analysis}

Statistical analysis was carried out using the MannWhitney test with differences at $p<0.05$ considered to be statistically significant.

\section{Results}

\section{Exposure of nanoparticle in chamber}

Figure 1 and 2 show that scanning electron photomicrographs of $\mathrm{NiO}$ and $\mathrm{TiO}_{2}$ nanoparticles. The particles in the chamber were well-dispersed, though they were agglomerates. The daily mean diameters of $\mathrm{NiO}$ and $\mathrm{TiO}_{2}$ in the exposure chamber for 4 wk inhalation were $139 \pm 12 \mathrm{~nm}$ and $51 \pm 9 \mathrm{~nm}$, respectively ${ }^{12)}$.
The daily average concentrations of the particle number of $\mathrm{NiO}$ and $\mathrm{TiO}_{2}$ were $1.0 \pm 0.5 \times 10^{5} / \mathrm{cm}^{3}$ and $2.8 \pm 0.9 \times 10^{5} / \mathrm{cm}^{3}$, respectively ${ }^{12)}$.

\section{Body and organ weight in rat (Table 2)}

There were no significant differences of body weight and wet weight of the lung, liver, kidney, and spleen among the unexposed, $\mathrm{NiO}$, and $\mathrm{TiO}_{2}$ exposure groups after $4 \mathrm{~d}$ to 3 months from the inhalation exposure.

Total cell count in BALF (Fig. 3)

The total cell count in BALF was significantly increased in the $\mathrm{NiO}$ exposure group $4 \mathrm{~d}$ after the end of inhalation. Thereafter the total cell count was decreased in the $\mathrm{NiO}$ exposure group and there was no difference as compared to the unexposed group after 3 months. On the other hand, there was no difference between the $\mathrm{TiO}_{2}$ exposure group and the unexposed group throughout the observation period. 


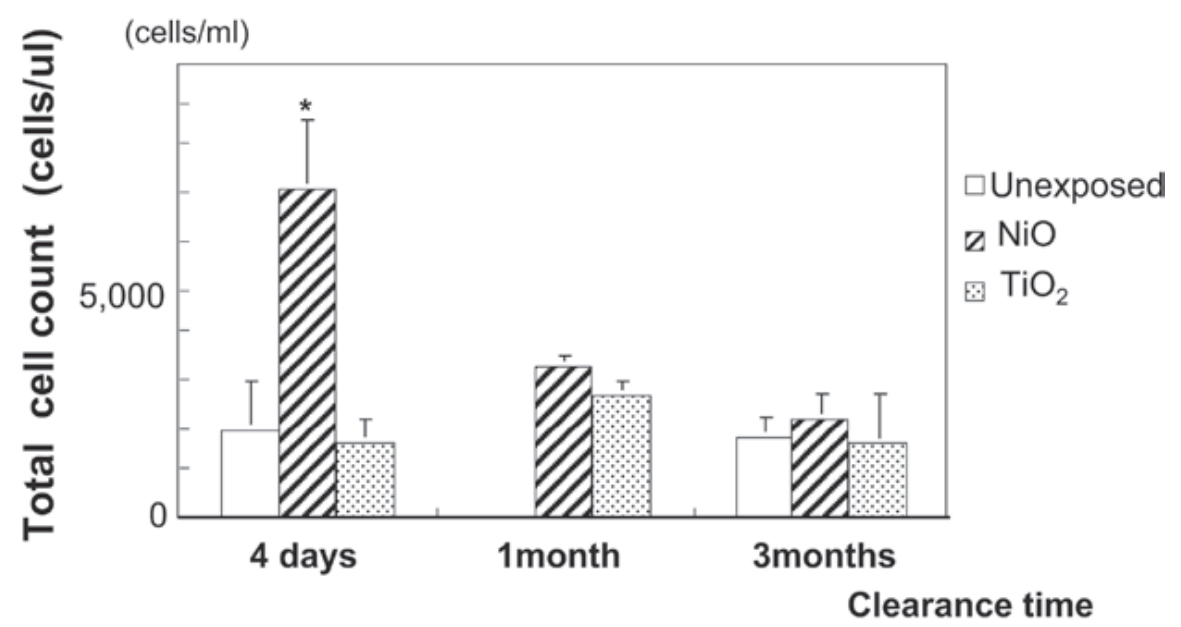

Fig. 3. Total cell counts in BALF by inhaled nanoparticles.

Transient increase in total cells in BALF was observed in $\mathrm{NiO}$ nanoparticles, but not in $\mathrm{TiO}_{2}$ nanoparticles. Each column and bar represents the mean $\pm \mathrm{SD}$ of five rats. An asterisk indicates a statistically significant difference of $p<0.05$ compared to each unexposed group.

Gene expression of MMP-2, TIMP-2 and type I collagen (Fig. 4A-C)

Figure 4A shows gene expression of MMP-2 in rat lungs exposed to metal oxide nanoparticles.

Exposure to $\mathrm{NiO}$ did not increase the level of MMP-2 mRNA in the lung at any observation time. Exposure to $\mathrm{TiO}_{2}$ also did not change the gene expression of MMP-2 at any time.

Figure 4B and 4C also show gene expressions of TIMP-2 and type I collagen in rat lungs exposed to metal oxide nanoparticles. Exposure to not only $\mathrm{NiO}$ but $\mathrm{TiO}_{2}$ did not change the gene expression of TIMP-2 and type I collagen in rat lungs at any observation time.

\section{Pathological futures (Figs. 5-6)}

A histopathologic feature of rat lung at $4 \mathrm{~d}$ and 1 month after the 4-wk inhalation exposure is shown in Figs. 5 and 6. The minimum transient infiltration of neutrophils and alveolar marcophages was observed in rat lung at the acute phase after the inhalation exposure of $\mathrm{NiO}$ nanoparticles only and not at any other observation time. As for the histopathologic feature of rat lung inhaled $\mathrm{TiO}_{2}$, no inflammatory or fibrotic changes were observed at any observation time.

\section{Discussion}

In the present study we performed an inhalation study of $\mathrm{NiO}$ and $\mathrm{TiO}_{2}$ using an ultrasonic nebulizer and a pressurized nebulizer, respectively, and measured size and particle number of nanoparticles in the chamber. Since the standard deviation of size and particle number of both nanoparticles in the chamber was not so large, the present study made it possible to carry out inhalation exposure to $\mathrm{NiO}$ and $\mathrm{TiO}_{2}$ nanoparticles with a stable particle size and number concentration ${ }^{10)}$. However, the agglomerated size of $\mathrm{NiO}$ nanoparticles was not nanoscale, but was more than $100 \mathrm{~nm}$. Although we examined the experimental condition in a $\mathrm{NiO}$ inhalation system using an ultrasonic nebulizer in order to reduce the agglomerated diameter, we think that the minimalization of the size is limited under the condition. On the other hand, the size of $\mathrm{TiO}_{2}$ agglomerated nanoparticles was less than $100 \mathrm{~nm}$ using the inhalation system using a pressurized nebulizer. We consider that the latter system may be a suitable one to keep the nanoscale of agglomerated nanoparticles.

Histopathological examination found minimal inflammation in $\mathrm{NiO}$ and no inflammation in $\mathrm{TiO}_{2}$. With regard to the inflammatory effect of $\mathrm{NiO}$, we carried out an intratracheal instillation study of nanoscale $\mathrm{NiO}$ nanoparticles and reported that they caused persistent pulmonary inflammation with a low dose ${ }^{13,14)}$. Lu et al. ${ }^{15)}$ also reported that $\mathrm{NiO}$ nanoparticles caused pulmonary inflammation in their intratracheal instillation study in mice. On the other hand, with regard to the inflammatory effect of $\mathrm{TiO}_{2}$ nanoparticles, Warheit et al. ${ }^{16)}$ reported that their intratracheal instillation study showed only transient inflammation in lung tissue. Kobayashi et al. ${ }^{17,}{ }^{18)}$ also carried out an intratracheal instillation study of anatase $\mathrm{TiO}_{2}$ particles with different primary diameter and agglomeration states (size of agglomeration) in rats and compared the effects of particles on the lung. As a result, exposure to $\mathrm{TiO}_{2}$ particles showed transient inflammation at a dose of $5 \mathrm{mg} / \mathrm{kg}$ that disappeared from $1 \mathrm{wk}$ to 1 month after the instil- 
A: Gene expression of MMP-2 in rat lung

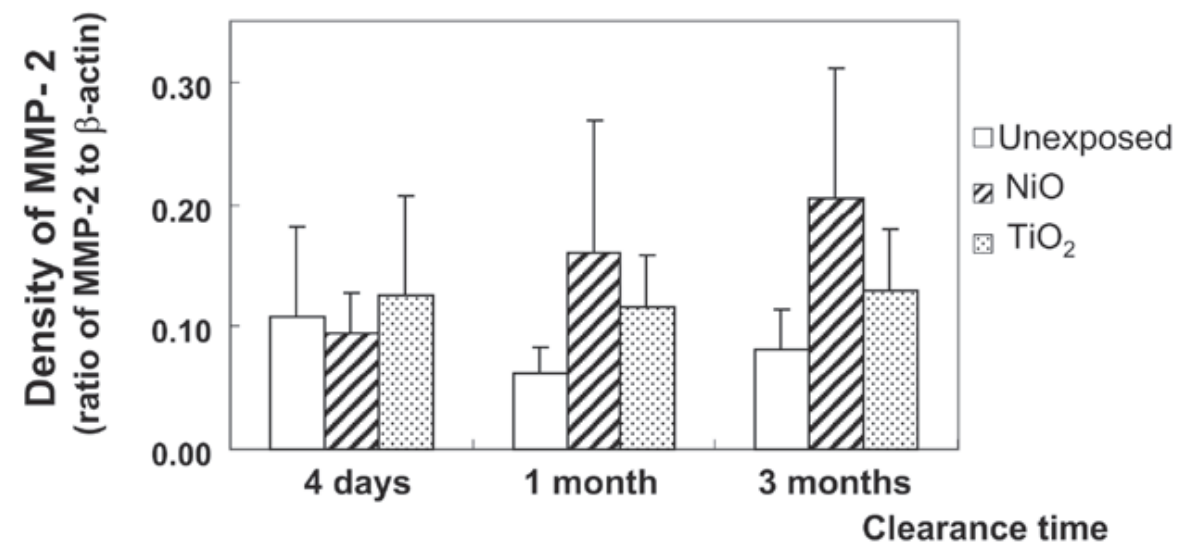

B: Gene expression of TIMP-2 in rat lungs

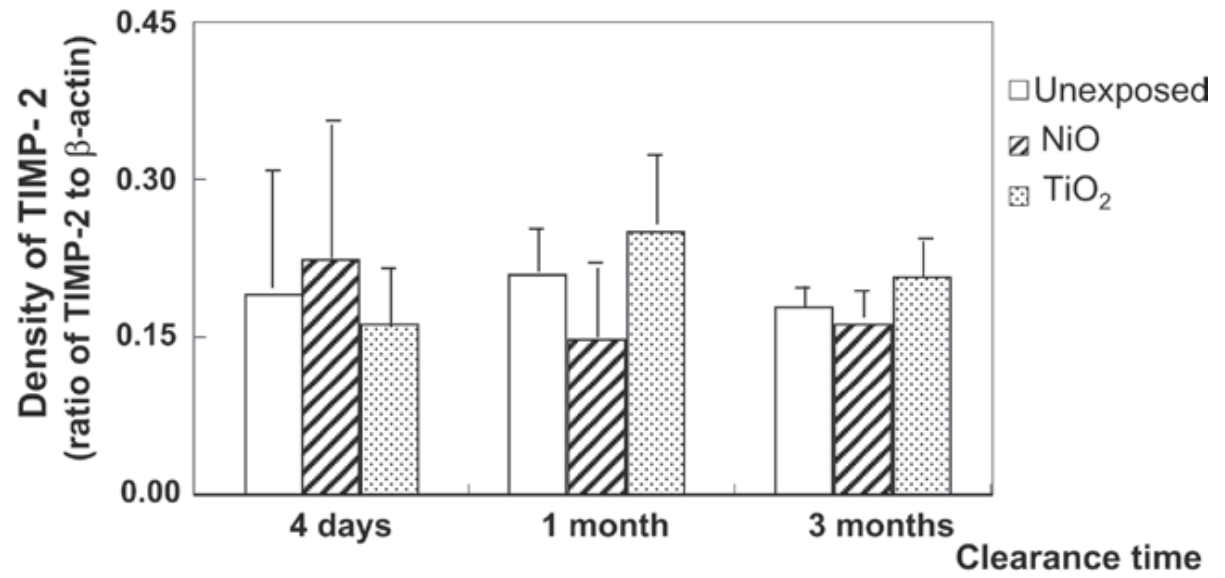

C: Gene expression of collagen in rat lungs

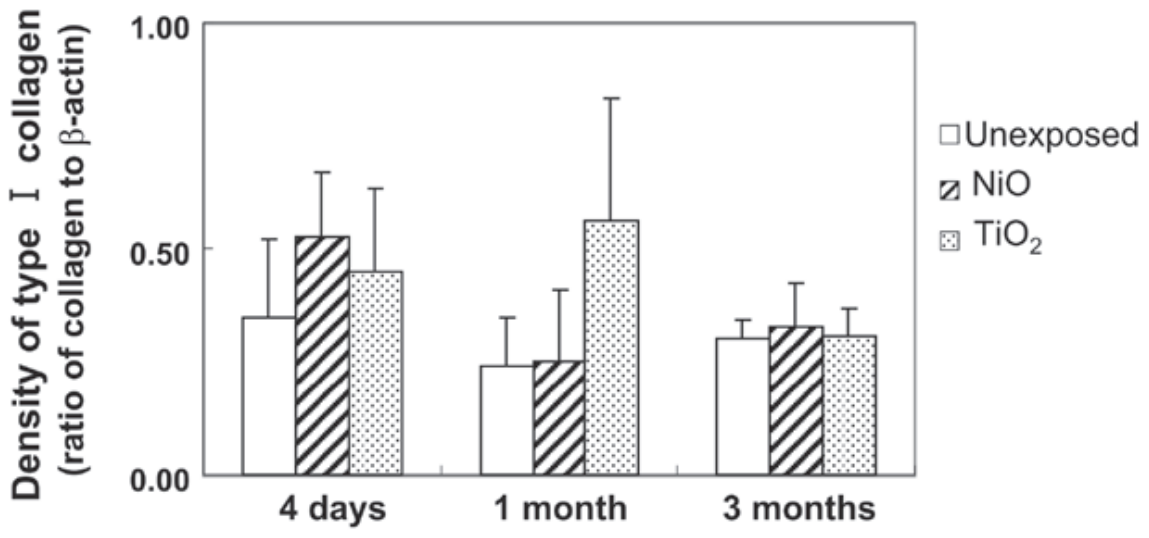

\section{Clearance time}

Fig. 4. Expression of matrix-related gene in rat lungs in inhalation study.

A: Gene expression of MMP-2 in lung by inhaled nanoparticles. B: Gene expression of TIMP-2 in lung by inhaled nanoparticles. C: Gene expression of type I collagen in lung by inhaled nanoparticles. Inhalation of $\mathrm{NiO}$ and $\mathrm{TiO}_{2}$ did not induce gene expression of MMP-2, TIMP-2 and type I collagen mRNA in rat lung. Each column and bar represents the mean $\pm \mathrm{SD}$ of five rats. 

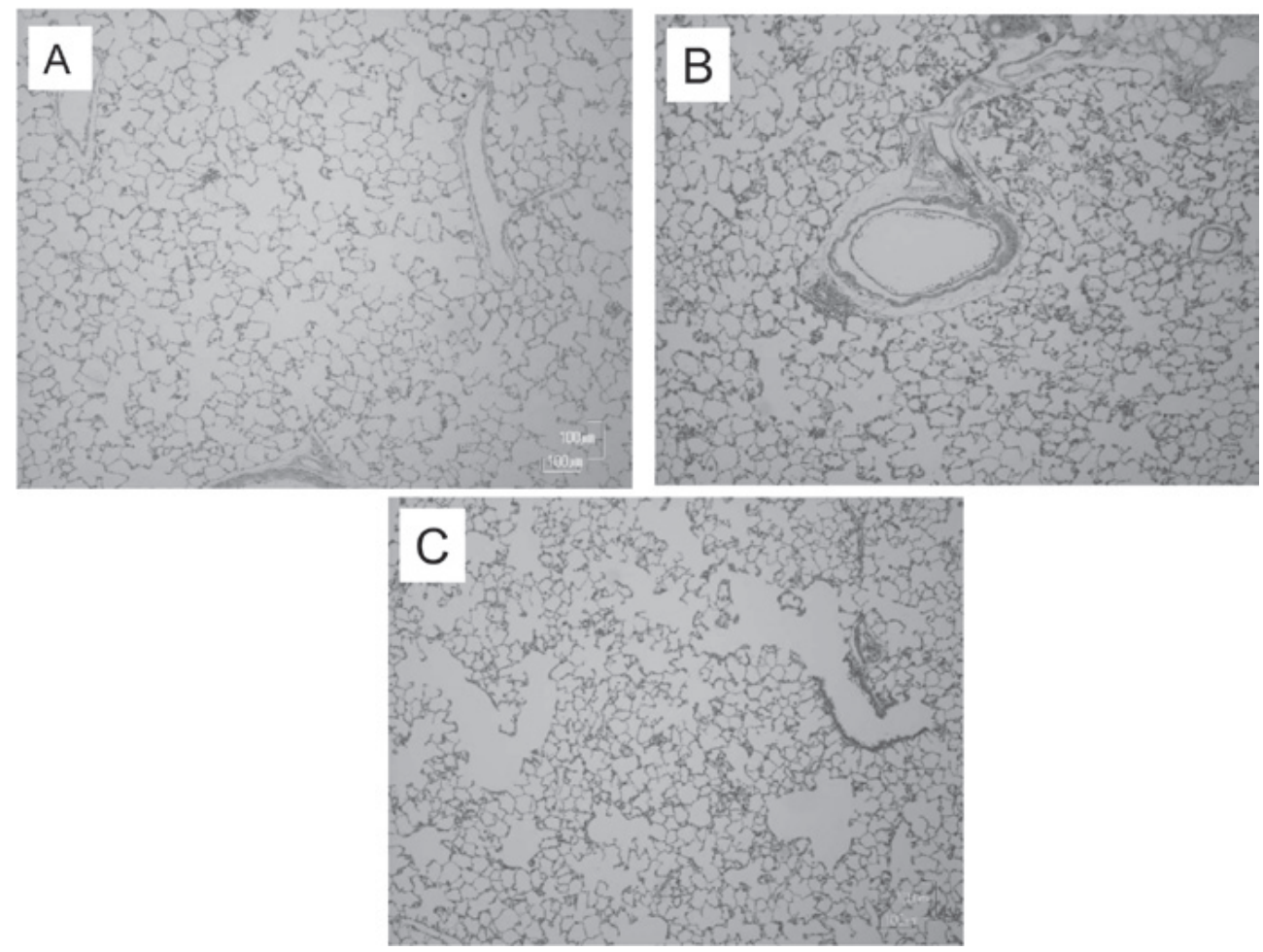

Fig. 5. Histopathological features of rat lung at $\mathbf{4} \mathbf{d}$ after inhalation study. A: unexposed, $\mathrm{B}$ : $\mathrm{NiO}$ exposed group, $\mathrm{C}: \mathrm{TiO}_{2}$ exposed group.
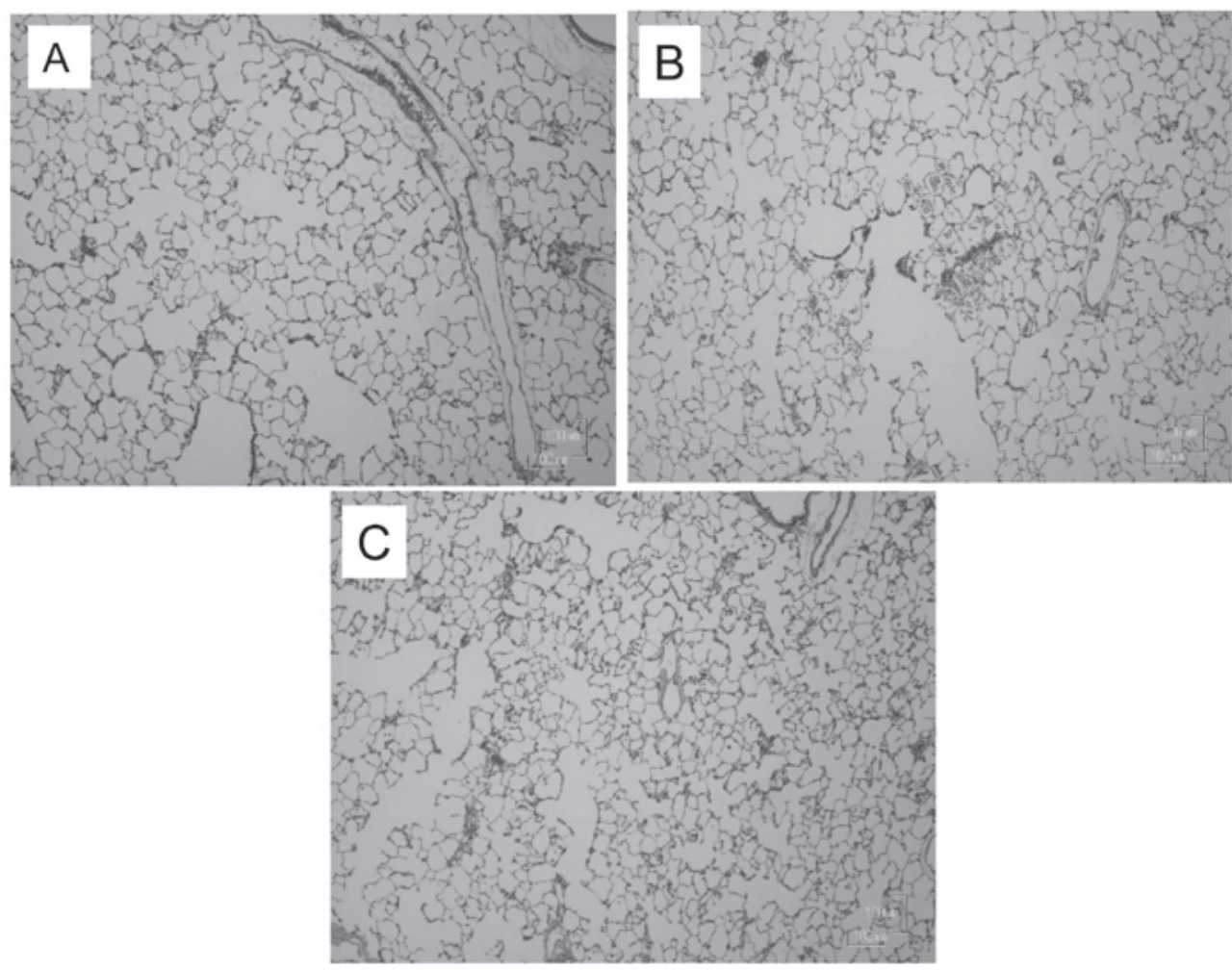

Fig. 6. Histopathological features of rat lung at 1 month after inhalation study. A: unexposed, $\mathrm{B}: \mathrm{NiO}$ exposed group, $\mathrm{C}: \mathrm{TiO}_{2}$ exposed group. 
lation; the recovery from inflammation was nearly the same irrespective of the primary diameter and agglomeration states of $\mathrm{TiO}_{2}$ particles. Thus, the inflammatory response of $\mathrm{NiO}$ and $\mathrm{TiO}_{2}$ in the present study is likely to be consistent with their previous reports of inflammatory effect by $\mathrm{NiO}$ and $\mathrm{TiO}_{2}$.

The expression of MMP in the rat lung after inhalation exposure to nanoparticles was not increased in either $\mathrm{NiO}$ or $\mathrm{TiO}_{2}$. As to the association between inflammatory lesion and MMP-2, there were reports that MMP-2 is associated with the infiltration of inflammatory cells such as neutrophil and eosinophil, and that the expression of MMP-2 was found to be increased in granuloma of sarcoidosis, a granulomatous inflammatory disease $^{19)}$. As for pulmonary inflammation caused by inhaled aerosol, we also previously conducted a longterm exposure study of toner and found mild infiltration of inflammatory cells, no increase of the expression of MMP-2 in the low-dose group, and an increased expression of MMP-2 in the high-dose group ${ }^{20)}$. The expression of MMP-2 was not increased in very mild inflammation in the present and previous studies. MMP-2 may not be associated with infiltration of inflammatory cells at the early stage of inflammation but may be associated with subsequent persistence or progress of inflammation. Further study is needed to examine the association between aerosol exposure and the expression of MMP.

The present study showed no changes in the expression of TIMP-2 in rat lung exposed to $\mathrm{NiO}$ or $\mathrm{TiO}_{2}$. An increase in gene expression of TIMP-2 was found in BALF in patients with granulomatous inflammatory disease ${ }^{18)}$. The TIMP-2 gene works not only to suppress the expression of MMP-2 but also to promote fibrosis $^{9}$. The result that pulmonary fibrosis was not found after exposure to $\mathrm{NiO}$ or $\mathrm{TiO}_{2}$ is consistent with the result that the expression of TIMP-2 was not increased. However, studies have reported that the expression of TIMP was decreased in inflammation and thus the MMP activity was relatively increased. Our long-term inhalation study of toner also showed a decrease of TIMP-2 ${ }^{20)}$. Although the present study did not show this tendency, the large discrepancies of gene expression between MMP-2 and TIMP-2 in lung exposed to NiO suggest that relatively increased MMP-2 activity may be involved with very mild inflammation caused by $\mathrm{NiO}$.

There was no stimulative effect of $\mathrm{NiO}$ or $\mathrm{TiO}_{2}$ on type I collagen production. Histopathological examination did not show obvious deposition of collagen in either particle group. We previously instilled $200 \mu \mathrm{g}$ of $\mathrm{NiO}$ particles intratracheally to observe for 6 months and also did not find marked fibrosis $\left.{ }^{13}, 14\right)$. The pulmonary deposition of the present study (deposited amount
$4 \mathrm{~d}$ after the end of the inhalation) was $29 \pm 44 \mu \mathrm{g}$ $\mathrm{NiO}^{10)}$. Considering the dose-dependence of an intratracheal instillation study, no collagen deposition in the present study is likely to be reasonable.

In summary, we exposed rats to $\mathrm{NiO}$ and $\mathrm{TiO}_{2}$ nanoparticles by inhalation at particle size and concentration in a stable manner by using an original generation system for $4 \mathrm{wk}$. There were no significant gene expression of MMP-2 and TIMP-2 in both groups compared with the unexposed group. Since a short-term inhalation study of nanoparticles could be carried out in minimal agglomeration size and the result showed an inflammatory tendency in $\mathrm{NiO}$ and not in $\mathrm{TiO}_{2}$, it is suggested that both particles reflect the biological effect as nanoparticles.

\section{Acknowledgements}

This study was supported by a Grant of the New Energy and Industrial Technology Development Organization (NEDO) in Japan.

\section{References}

1) ISO Nanotechnologies-Terminology and definitions for nanoparticles (2008) ISO-TS 27687

2) Kwon JT, Kim DS, Minai-Tehrani A, Hwang SK, Chang SH, Lee ES, Xu CX, Lim HT, Kim JE, Yoon BI, An GH, Lee KH, Lee JK, Cho MH (2009) Inhaled fluorescent magnetic nanoparticles —induced extramedullary hematopoiesis in the spleen of mice. $\mathrm{J}$ Occup Health 51, 423-31.

3) Watanabe N, Oonuki Y (1999) Inhalation of diesel engine exhaust affects spematogenesis in glowing male rats. Environ Health Perspect 107, 539-44.

4) Chen G, Song G, Jiang L, Zhang Y, Zhao N, Chen B, Kan H (2008) Short-term effects of ambient gaseous pollutants and particulate matter on daily mortality in Shanghai, China. J Occup Health 50, 41-7.

5) Kwon JT, Hwang SK, Jin H, Kim DS, Minai-Tehrani A, Yoon HJ, Choi M, Yoon TJ, Han DY, Kang YW, Yoon BI, Lee JK, Cho MH (2008) Body distribution of inhaled fluorescent magnetic nanoparticles in mice. J Occup Health 50, 1-6.

6) Toya T, Takata A, Otaki N, Takaya M, Serita F, Yoshida K, Kohyama N (2010) Pulmonary toxicity induced by intratracheal instillation of coarse and fine particles of cerium dioxide in male rats. Ind Health 48, 3-11.

7) Ogami A, Morimoto Y, Myojo T, Oyabu T, Murakami M, Todoroki M, Nishi K, Kadoya C, Yamamoto M, Tanaka I (2009) Pathological features of different sizes of nickel oxide following intratracheal instillation in rats. Inhal Toxicol 21, 812-8.

8) Song Y, Li X, Du X (2009) Exposure to nanoparticles 
is related to pleural effusion, pulmonary fibrosis and granuloma. Eur Respir J 34, 559-67.

9) Gill SE, Parks WC (2008) Metalloproteinases and their inhibitors: regulators of wound healing. Int $\mathrm{J}$ Biochem Cell Biol 40, 1334-47.

10) Oyabu T, Ogami A, Morimoto $Y$, Shimada $M$, Lenggoro W, Okuyama K, Tanaka I (2007) Biopersistence of inhaled nickel oxide nanoparticles in rat lung. Inhal Toxicol 19 (Suppl 1), 55-8.

11) Shimada M, Wang WN, Okuyama K, Myojo T, Oyabu T, Morimoto Y, Tanaka I, Endoh S, Uchida K, Ehara K, Sakurai H, Yamamoto K, Nakanishi J (2009) Development and evaluation of an aerosol generation and supplying system for inhalation experiments of manufactured nanoparticles. Environ Sci Technol 43, 5529-34.

12) Tanaka I (2005) Management number 100008041. Feasibility Study on Risk Assessment of Nanoparticles - Preparatory Experiments to Evaluate the Effects of Nanoparticle Inhalation on Humans- http://www. nedo.go.jp/database/index.html Accessed October 7, 2010.

13) Nishi K, Morimoto Y, Ogami A, Murakami M, Myojo T, Oyabu T, Kadoya C, Yamamoto M, Todoroki M, Hirohashi M, Yamasaki S, Fujita K, Endo S, Uchida K, Nakanishi J, Tanaka I (2009) Expression of cytokineinduced neutrophil chemoattractant in rat lungs by intratracheal instillation of nickel oxide nanoparticles. Inhal Toxicol 21, 1030-9.

14) Morimoto $Y$, Ogami A, Todoroki M, Yamamoto $M$, Murakami M, Hirohashi M, Oyabu T, Myojo T, Nishi K, Kadoya C, Yamasaki S, Nagatomo H, Fujita K, Endoh S, Uchida K, Yamamoto K, Kobayashi N, Nakanishi J, Tanaka I (2010) Expression of inflammation-related cytokines following intratracheal instillation of nickel oxide nanoparticles. Nanotoxicology 4, 161-76.

15) Lu S, Duffin R, Poland C, Daly P, Murphy F, Drost E, MacNee W, Stone V, Donaldson K (2009) Efficacy of simple short-term in vitro assays for predicting the potential of metal oxide nanoparticles to cause pulmonary inflammation. Environ Health Perspect 117, 241-7.

16) Warheit DB, Webb TR, Sayes CM, Colvin VL, Reed KL (2006) Pulmonary instillation studies with nanoscale $\mathrm{TiO}_{2}$ rods and dots in rats: toxicity is not dependent upon particle size and surface area. Toxicol Sci 91, 227-36.

17) Kobayashi N, Naya M, Endoh S, Maru J, Yamamoto K, Nakanishi J (2009) Comparative pulmonary toxicity study of nano- $\mathrm{TiO}_{2}$ particles of different sizes and agglomerations in rats: different short- and long-term post-instillation results. Toxicology 264, 110-8.

18) Morimoto $Y$, Kobayashi N, Shinohara N, Myojo $T$, Tanaka I, Nakanishi J (2010) Hazard assessments of manufactured nanomaterials. J Occup Health 52, 325-34.

19) Piotrowski WJ, Nawrocka-Kunecka A, Antczak A, Marczak J, Biernacki R, Kordek P, Kurmanowska Z, Górski P (2009) Metalloproteinases MMP-9, MMP-2 and their tissue inhibitors TIMP-1, TIMP-2 in peripheral transbronchial lung biopsies of patients with sarcoidosis. Pol Arch Med Wewn 119, 628-35.

20) Morimoto $Y$, Kim H, Oyabu T, Hirohashi M, Nagatomo H, Ogami A, Yamato H, Obata Y, Kasai H, Higashi T, Tanaka I (2005) Negative effect of longterm inhalation of toner on formation of 8-hydroxydeoxyguanosine in DNA in the lungs of rats in vivo. Inhal Toxicol 17, 749-53. 